\title{
Causes of Partial Male Sterility in an Inbred Maize Line
}

\author{
Marli Aparecida Defani-Scoarize', Maria Suely Pagliarini ${ }^{1 *}$ \\ and Celso Gonçalves Aguiar ${ }^{2}$ \\ ${ }^{1}$ Department of Cell Biology and Genetics, State University of Maringá, \\ 87020-900, Maringá-Paraná-Brazil \\ ${ }^{2}$ Organization of Cooperatives of the State of Paraná, Cascavel-Paraná-Brazil
}

Accepted July 26, 1995

Male sterility, which is characterized by the absence of pollen grain production, is common in higher plants. It occurs spontaneously in natural populations or may be experimentally induced with the use of mutagens.

In general, male sterility is divided into three types: genetic, cytoplasmic and geneticcytoplasmic. In maize, male sterility may result from mutations in nuclear genes (genetic male sterility - GMS) or in mitochondrial genes (cytoplasmic male sterility-CMS). More than twenty mutant genes that confer the male-sterile phenotype have been identified thus far in this species. Most of them are recessive and are generically denoted $m s$. Whereas genetic male sterility is of Mendelian inheritance, cytoplasmic male sterility is maternally transmitted (Gabay-Laughnan and Laughnan 1993).

The $m s$ genes cause full collapse of microsporogenesis, while macrosporogenesis is unaffected. Each mutant $m s$ gene acts in a specific manner and is sex, time, site and stage specific (Nirmala and Kaul 1993). Each gene is unique in its action. Kaul (1988) described the action of $m s$ genes in countless species of higher plants.

When compared with normal fertile plants, male-sterile plants present smaller, wrinkled and non-dehiscent anthers. The occurrence of a line with plants with these characteristics in a maize breeding program led the agronomist in charge to look for an explanation for this fact. This was an inbred line with promising agronomic traits for hybrid production. However, with the advance of inbreeding, a larger number of totally or partially male-sterile plants appeared at each generation, a fact that ruled out the use of this line in crosses.

\section{Material and methods}

The line under study was selected from the variety BR 106 (National Maize and Sorghum Center/EMBRAPA) and belongs to inbreeding programs for the derivation of hybrids of the Organization of Cooperatives of the State of Paraná (Paraná, Brazil). The line has been submitted to six selfing cycles.

The male inflorescences were collected during the ideal phase for meiotic study and fixed in Carnoy ( 3 parts alcohol: 1 part acetic acid) for $24 \mathrm{hr}$. After fixation, the material was transferred to $70 \%$ alcohol and stored fronzen until the time for use. Microsporocytes were prepared by the squash technique and stained with $1 \%$ propionic carmine. Sixteen plants were studied. The number of cells analyzed to determine meiotic stability ranged from 300 to 1898 per plant. All phases of meiosis were analyzed and all abnormalities were recorded. 


\section{Results}

During flower dissection, many were found to present empty anthers or anthers containing few microsporocytes. In the older branches of the inflorescence, whose microsporocytes had completed meiosis, the flowers acquired the characteristic male-sterile aspect, i.e., they were transparent and dry.

Despite the irregularities, the meiotic process continued to the end and microsporocytes filled the anthers. Starting from the formation of pollen grains, since most of them became abortive, there was total or partial anther collapse. The inflorescences with a male sterile appearance were those most severely affected by meiotic irregularities.

Table 1 presents the results of the meiotic analysis carried out on each plant. It can be seen that the plants were not equally affected by meiotic irregularities. Whereas some plants were highly affected, others had a more regular meiotic behavior. Among the irregularities observed, particularly outstanding were univalent chromosomes, irregular segregation and micronuclei in meiosis I and II, sticky chromosomes during all phases of meiosis, absence of cytokinesis at the end of first and/or second division, defective cytokinesis, abnormal spindles, cell fusion, giant cells, chromosome fragmentations, aneuploid and polyploid cells etc. As a consequence of these abnormalities, the final product of meiosis was highly affected. Microspore dyads, triads and polyads, tetrads with microcytes and multinucleate microspores were frequent. Pollen grains of varying size were observed. Figs. 1, 2 and 3 illustrate the various types of meiotic irregularities observed in the line under study.

\section{Discussion}

The cause of male sterility in higher plants are countless. The $m s$ genes exhibit a wide diversity of action ranging from complete absence of the androceum to the production of inviable pollen grains due to disorders of microsporogenesis. They act with remarkable precision on defined stages of microsporogenesis (premeiosis, meiosis and postmeiosis) and prevent the normal development of sporogenic tissue, tapetum cells, pollen mother cells and microspores (Singh 1993).

Kaul (1988) reported that a small number of premeiotic $m s$ genes act on sporogenic cells, archesporial tissues and pollen mother cells. Other $m s$ genes are effective during meiotic division, when they act by disturbing the normal sequence of meiosis or by affecting a particular stage. As the consequence of an anomalous chromosome behavior, abnormal microspores are formed. Most $m s$ genes, however, act on postmeiotic stages soon after tetrad formation, blocking the formation of normal pollen grains.

It is estimated that among the species that present male sterility, $80 \%$ of $m s$ genes arose spontaneously, whereas in the remaining cases they were induced by mutagens (Kaul 1988). In maize, Golubovskaya (1989) reported more than twenty genes that affect meiosis, most of which cause total or partial male and/or female sterility in the affected plants. Many of these genes were obtained by mutation induction. Considering only those that specifically cause male sterility, including those responsible for cytoplasmic male sterility, there is an enormous number of genes coding for this trait that have been detected in maize. The first report was that of Eyster (1921), concerning a single nuclear gene conferring genetic male sterility. Male sterility of extranuclear inheritance in maize has also been known for more than 60 years (Rhoades 1931).

It is quite interesting to compare the meiotic irregularities that led to male sterility in the present line to data for other plants in which this trait was caused by meiotic disorders. Univalent chromosomes accompanied by irregular segregations were considered to be respon- 


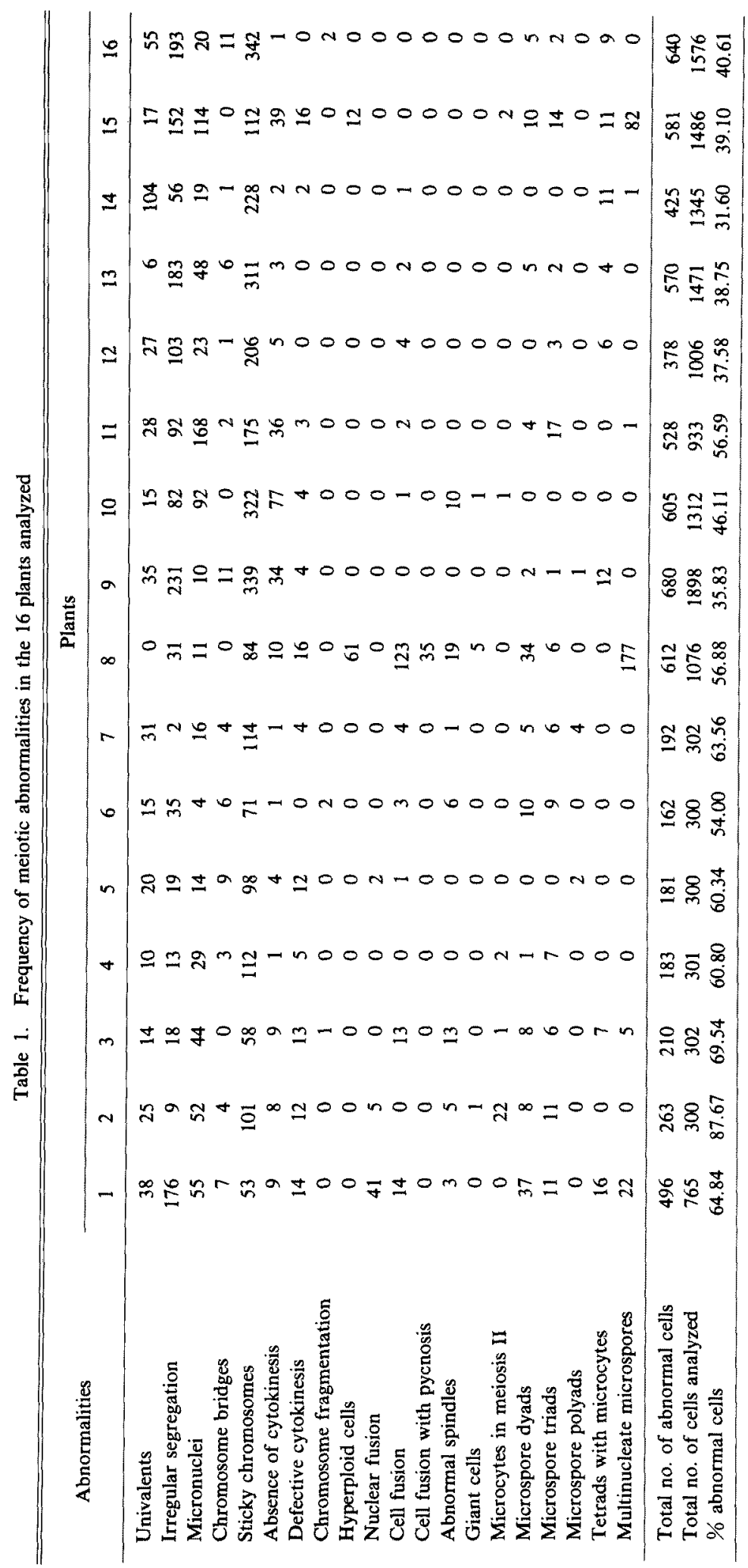




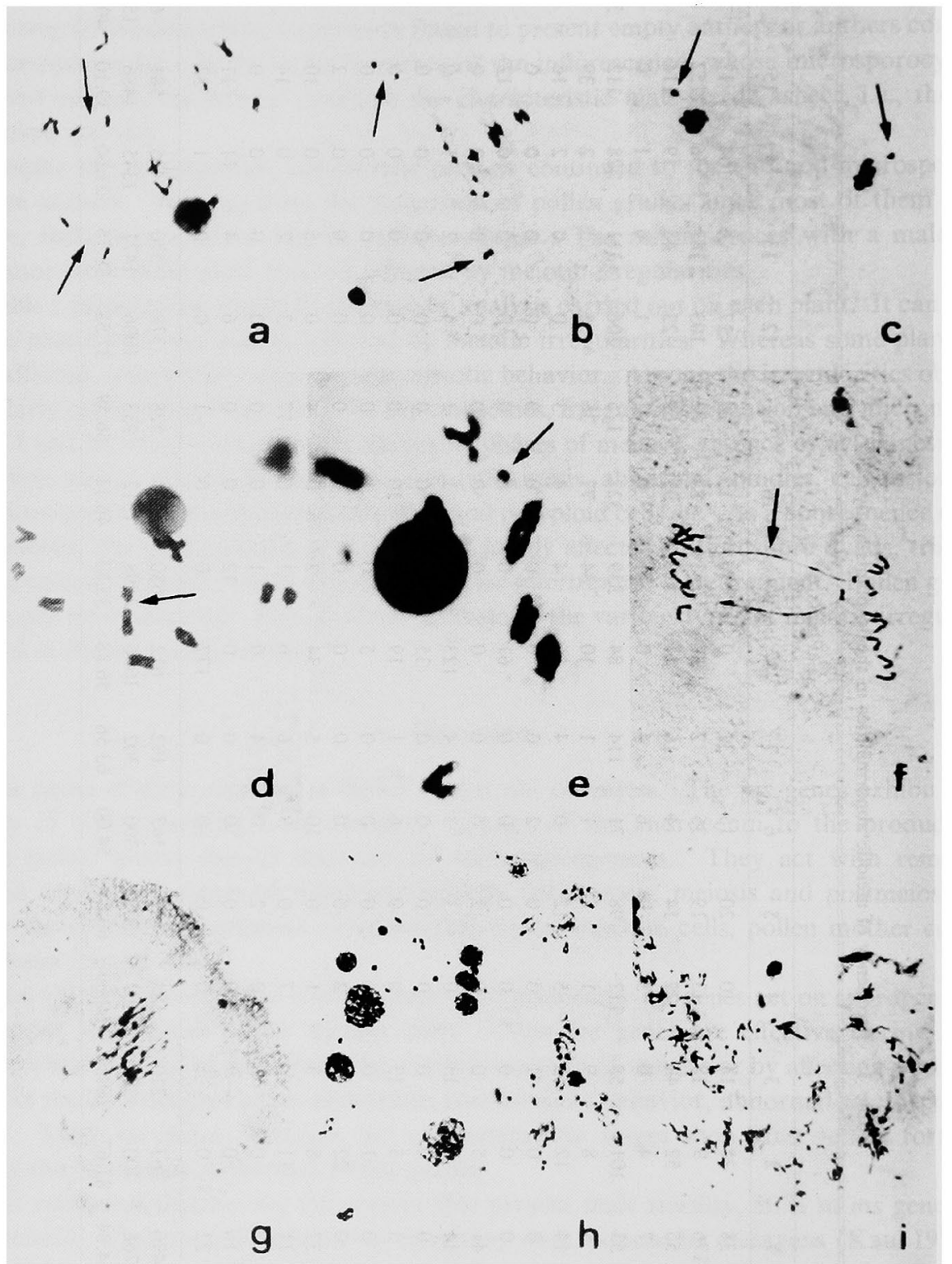

Fig. 1. Most common abnormalities during meiosis I. a) Microsporocyte in diakinesis exhibiting two pairs of univalent chromosomes and some bivalents with a terminal chiasma; b) irregular chromosome segregation at metaphase $I$; c) micronuclei in telophase $I$; d,e) break points and fragments visualized during diakinesis; f) chromosome bridges in anaphase $I$; g) sticky chromosomes in anaphase I. Observe the pulverized aspect of the chromosomes and fragments in the cytoplasm; h, i) cell fusion involving various microsporocytes. Nuclei of different sizes and countless micronuclei can be observed in $h$.

sible for the male sterility observed in Hevea brasiliensis (Amma et al. 1990) and partially responsible for the sterility of Pisum sativum (Kaul and Nirmala 1991, Nirmala and Kaul 1994a). A high frequency of univalent chromosomes, irregular segregation and micronucleus 


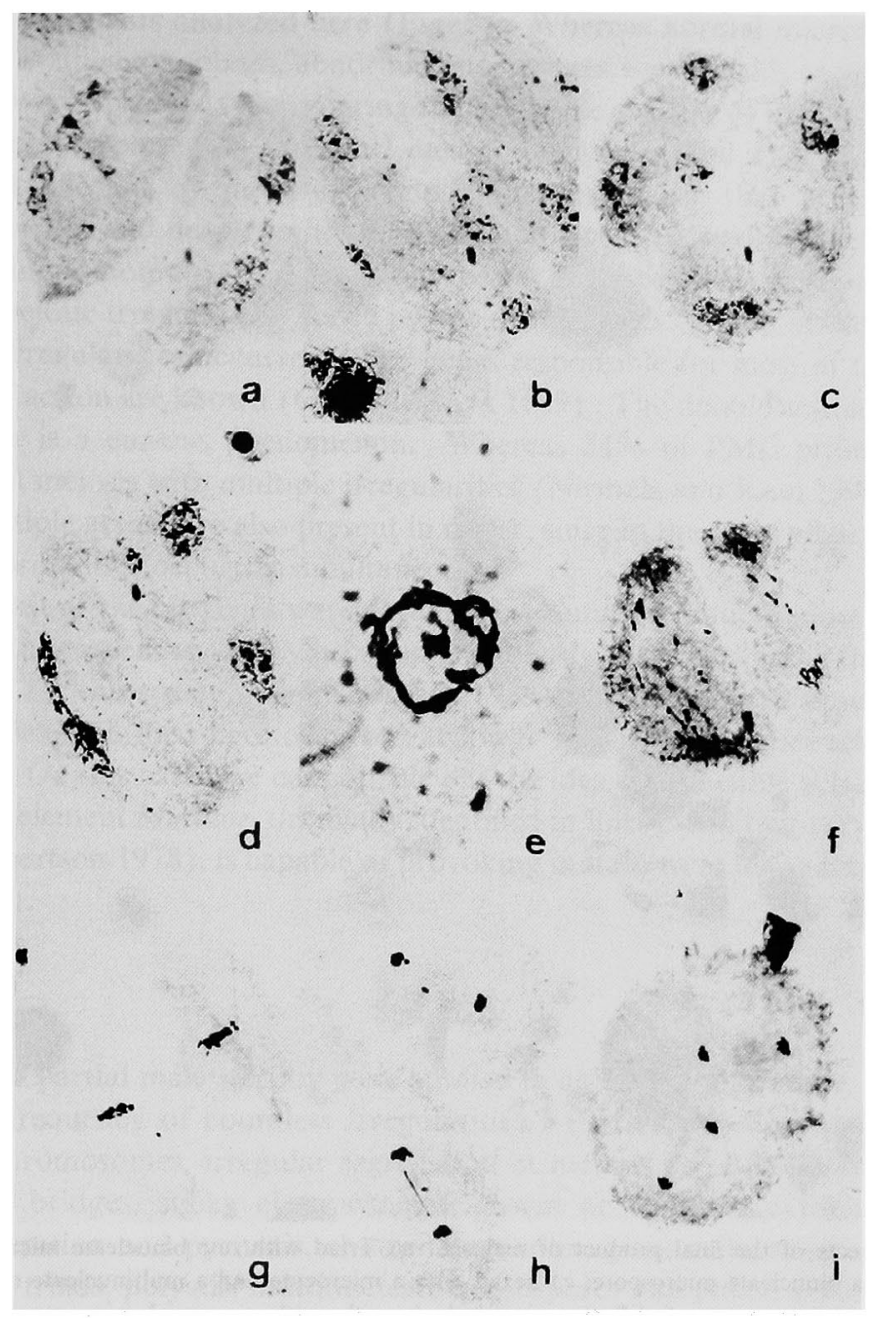

Fig. 2. Abnormalities observed during meiosis II. a-d) Aspects of meiosis II of plant no. 8 with 4 n chromosomes; e, f) aspects of microsporocytes in prophase II and anaphase II exhibiting sticky chromosomes. In e all chromosomes were joined together, whereas in $f$ stickiness provoked irregular chromosome segregation. $\mathrm{g}, \mathrm{h}$ ) irregular chromosome segregation during metaphase II and anaphase II, respectively. In $\mathrm{h}$ a bridge with a fragment can be seen in one of the microsporocytes; i) anaphase II in a microsporocyte that did not undergo first cytokinesis.

formation was observed in all the plants of the line under study. These factors have been reported by Pagliarini $(1983,1989)$ and by Pagliarini et al. (1986) to be responsible, at least in part, for the low combining ability of inbred maize lines by affecting the production of viable pollen grains.

Other abnormalities detected in the plants studied here have been held responsible for male sterility also in other species. Chromosome breaks were described in Pisum sativum (Nirmala and Kaul 1993, 1994a, b) while bridges and fragments were described only by Nirmala and Kaul (1994a). Chromosome stickiness, an abnormality that occurs at high frequency among the plants studied, has also been the cause of male sterility in Pisum sativum (Kaul and Nirmala 1991, Nirmala and Kaul 1993, 1994a) and Carthamus tinctorius (Carapetian and Rupert 1977). Absent or defective cytokinesis leading to cenocytic microspores and microspores of different 


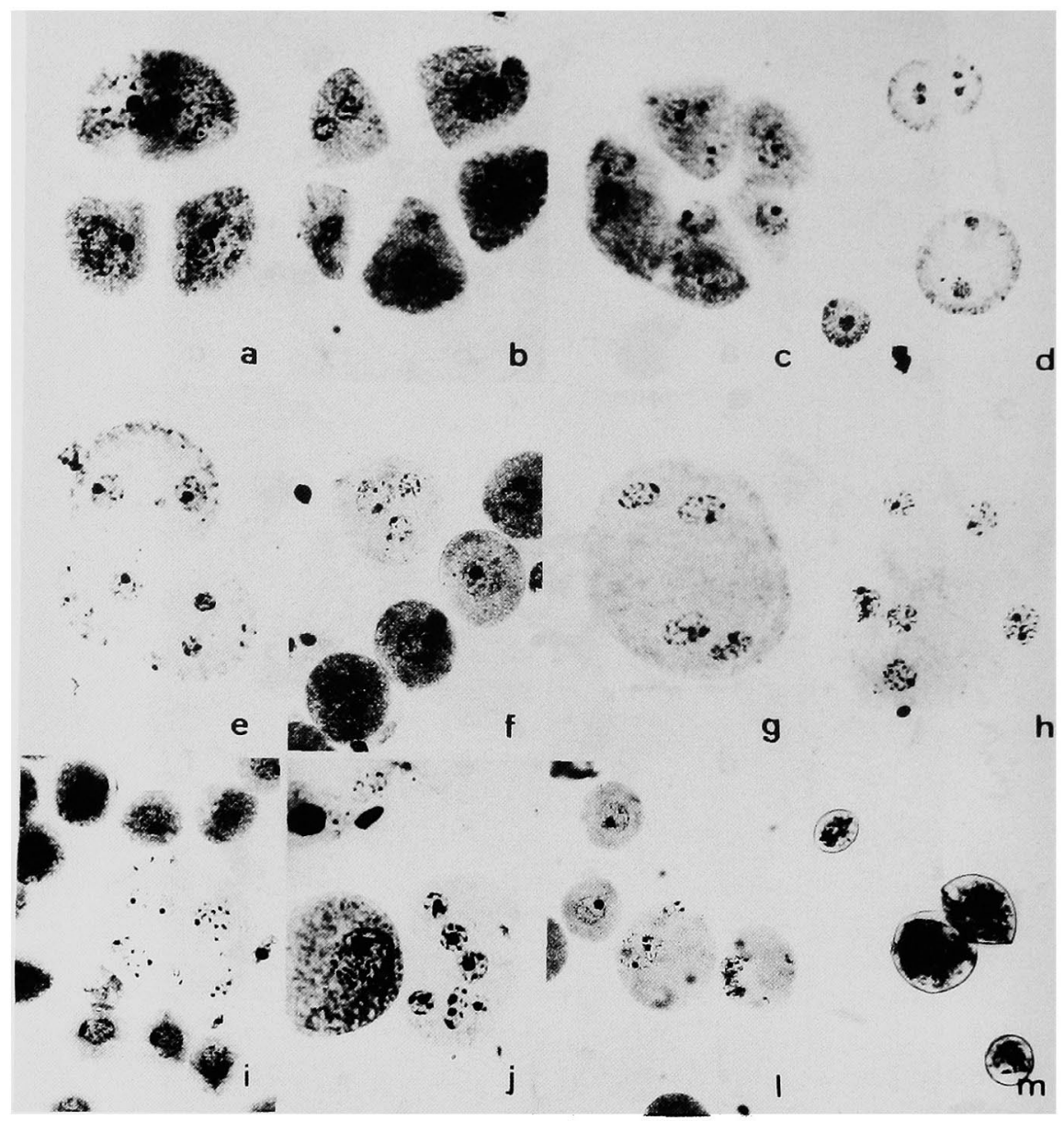

Fig. 3, Aspects of the final product of meiosis. a) Triad with one binucleate microspore; b) pentad with a binucleate microspore; c) hexad with a microcyte and a multinucleate microspore; d) binucleate microspores of different sizes side by side with a normal microspore; e) fused binucleate microspores with various micronuclei; f) trinucleate microspore side by side with normal microspores; g) tetranucleate microspore; h) hexanucleate microspore; i,j) plurinucleate microspores side by side with normal microspores; 1) abnormal microspores side by side with normal microspores; $m$ ) pollen grains of different sizes.

sizes has been reported for Pisum sativum (Nirmala and Kaul 1994a), Houttuynia cordata (Takahashi 1986), Glycine max (Albertsen and Palmer 1979, Skorupska and Nawracala 1980, Skorupska and Palmer 1990), Hordeum vulgare (Kaul and Nirmala 1991), and Impatiens sultani (Tara and Namboodiri 1974). The frequency of these types of irregularities was high also in the present study. Abnormal spindles were described in sterile Carthamus tinctorius (Carapetian and Rupert 1977), while cell fusion was considered to be one of the cause of male sterility in Pennisetum americanum (Rao et al. 1989). Chromosome degeneration was also detected in male sterile Hordeum vulgare (Kaul and Nirmala 1991) and Pisum sativum (Kaul and Nirmala 1991, Nirmala and Kaul 1993). As a result of these and other irregularities, the final product of meiosis in the male-sterile species described here was highly irregular. Monads, dyads, triads, abnormal tetrads and polyads gave origin to microspores of uneven size and multinucleate, cenocytic, fused etc. (Carapetian and Rupert 1977, Takahashi 1986, Rao and Devi 1989, Skorupska and Palmer 1990, Nirmala and Kaul 1993, 1994a, b). All of these forms 
were detected in the plants analyzed here (Fig. 3). Whereas normal microspores presented a dense and deeply stained cytoplasm, abnormal microspores were weakly stained. Pollen grains of different sizes were observed. Considering that the male sterility of this line was only partial, many microsporocytes presented a normal meiotic behavior, producing viable pollen grains. The plants most affected by meiotic irregularities were those that presented the highest frequency of branches and flowers with a male-sterile aspect in the inflorescence.

It is interesting to note that in most of the species described here male sterility was caused by few types of meiotic irregularities coded by one or few genes. In the maize line under study, however, many irregularities occurred. The genes responsible for most of these irregularities and their form of action are known (Golubovskaya 1989). The double action of the msg2 gene in Pisum sativum is a curious phenomenon. Whereas $34 \%$ of PMC present cytomixis, the remainder present meiosis with multiple irregularities (Nirmala and Kaul 1994a). It is possible that genes of multiple action are also present in maize, since in the same plant, such as plant no. 1 , countless abnormalities occurred simultaneously.

Although most of the $m s$ genes were obtained by mutation induction both in maize and in other species, in the present case they arose spontaneously. It is intriguing that so many genes already described for this species (Golubovskaya 1989) were manifested simultaneously. Most of the irregularities described here occurred at lower frequency in other selected lines of the same population. On this basis, we cannot rule out the idea of a possible action of transposons. The transposable element Mutator, originally identified in lines exhibiting very high frequencies of mutation (Robertson 1978), is capable of provoking mutations at many loci at the same time (Robertson 1985).

\section{Summary}

The causes of partial male sterility were studied in an inbred maize line. Meiotic analysis revealed a high frequency of countless irregularities. Particularly outstanding among them were univalent chromosomes, irregular segregation at meiosis I and II, micronuclei, chromosome breaks and bridges, sticky chromosomes, absent or defective cytokinesis, cell fusion, chromatin degeneration and pycnosis, abnormal spindles, giant cells, numerical chromosome variations, dyads, triads, polyads, multinucleate microspores and pollen grains of varying size. Although the frequency of irregularities was high, not all microsporocytes were affected. The present results are compared to literature data about genetic male sterility.

\section{References}

Albertsen, M. C. and Palmer, R. G. 1979. A comparative light and electron-microscopic study of microsporogenesis in male sterile (msl) and male fertile soybeans (Glycine max [L.] Merr.). Am. J. Bot. 66: 253-265.

Amma, C. K. S., Namboodiri, A. N. and Panikkar, A. O. N. 1990. Meiotic abnormalities in a sterile clone of Hevea brasilensis (Willd. ex Adr. de Juss.) Muell. Arg. Cytologia 55: 225-229.

Carapetian, J. and Rupert, E. A. 1977. Meiotic irregularities caused by interacting sterility genes in cultivated safflower (Carthamus tintctorius). Can. J. Genet. Cytol. 19: 103-109.

Eyster, L. A. 1921. Heritable characters of maize VII. Male sterile. J. Hered. 12: 138-144.

Gabay-Laughnan, S. and Laughnan, J. R. 1993. Male sterility and restorer genes in maize. In: The Maize Handbook. (Eds: Freeling, M. J. and Walbot, V.), Springer-Verlag, New York, 759 p.

Golubovskaya, I. N. 1989. Meiosis in maize: mei genes and conception of genetic control of meiosis. Adv. Genet. 26: 149-192.

Kaul, M. L. H. 1988. Male sterility in higher plants. Monogr. Theor. Appl. Genet. $\mathrm{N}^{\circ} 10$, Springer-Verlag, Berlin, $1005 \mathrm{p}$.

- and Nirmala, C. 1991. Male sterile gene action diversity in barley and pea. The Nucleus 34: 32-39.

Nirmala, C. and Kaul, M. L. H. 1993. Male sterility in Pea IV. Meiotic absence, arrest, breakdown and continuation. 
Cytologia 58: 247-255.

- and - 1994a. Male sterility in Pea V. Gene action during heterotypic and homotypic divisions. Cytologia 59: 4350.

- and - 1994b. Male sterility in Pea VI. Gene action duplicity. Cytologia 59: 195-201.

Pagliarini, M. S. 1983. Correlação entre frequêencia de quiasmas e capacidade de combinação em lìnhagens autofecundadas de milho (Zea mays L.): uma análise prévia. Rev. Unimar 5: 37-46.

- 1989. Avaliação da freqüência de quiasmas em milho (Zea mays L.) e suas implicações com a capacidade de combinação para a produção de grãos. (Doctoral Thesis, Escola Superior de Agricultura "Luiz de Queiroz"/ USP, Piracicaba-SP), 191 p.

-, Miranda Filho, J. B. and Aguiar-Perecin, M. L. R. 1986. Correlação entre frequiência de quiasmas e capacidade de combinação em linhagens autofecundades de milho. In: CONGRESSO NACIONAL DE MILHO E SORGO, 15, Maceió, 1984. Anais. Sete Lagoas, EMBRAPA, CNPMS, p. 183-188.

Rao, M. K. and Devi, K. U. 1989. Allelic relationship of four male sterility genes and nucleo-cytoplasmic interactions in the expression of male sterility in pearl millet, Pennisetum americanum (L.) Leeke. Theor. Appl. Genet. 77: $576-580$.

Rhoades, M. M. 1931. Cytoplasmic inheritance of male sterility in Zea mays. Science 73: 340-341.

Robertson, D. S. 1978. Characterization of a mutator system in maize. Mut. Res, 51: 21-28.

- 1985. Differential activity of the maize mutator $M u$ at different loci and in different cell lineages. Mol. Gen. Genet. 200: 9-13.

Singh, R. J. 1993. Plant Cytogenetics. CRC Press, Boca Raton, 391 p.

Skorupska, H. T. and Nawracala, J. 1980. Observation of pollen grains of soybean plants in male-sterile line Urbana msl. Genet. Pol. 21: 33-37.

- and Palmer, R. G. 1990. Additional sterile mutations in soybean, Glycine max (L.) Merr. J. Heredity 81: 296-300.

Takahashi, M. 1986. Microsporogenesis in a parthenogenetic species, Houttuynia cordata Thumb. (Saururaceae). Bot. Gaz. 147: 47-54.

Tara, C. P. and Namboodiri, A. N. 1974. Aberrant microsporogenesis and sterility in Impatiens sultani (Balsaminaceae). Am. J. Bot. 61: 585-591. 